INDO GLOBAL JOURNAL OF

PHARMACEUTICAL SCIENCES

ISSN 2249- 1023

\title{
Production of Tannase and Gallic Acid by Utilizing Agro- Industrial Wastes as Economical Raw Material and Purification of Tannase
}

\author{
Apoorva Gaur, K.E. Nandini, S. Krishna Sundari * \\ Department of Biotechnology, Jaypee Institute of Information Technology, Sector-62, Noida, U.P., India \\ Address for Correspondance: S. Krishna Sundari, krishna.sundari@jiit.ac.in ; skrishnasundari@gmail.com
}

\section{Keywords}

Aspergillus F1; Syzygium Cumini; Acacia Nilotica; Tannase.

\begin{abstract}
Research on utilization of agro wastes as economical raw material for the production of industrially important products are gaining importance these days. This boosts up high economic returns in many industrial practices and restricts the quantum of organic wastes reaching the landfills, helps to solve/minimize pollution problem. Present study was focused on exploring the abilities of laboratory isolates of Aspergillus F1 and bacterial strains (2.2 and 2.7) to produce value added products such as tannase and gallic acid by utilizing agro- residues. Different agro residues like jamun (Syzygium cumini), keekar (Acacia nilotica), corn husk powder, spent tea powder and powdered banana peel that were used in solid-state fermentation (SSF) both individually as well as in specific combinations with an intention to maximize enzyme production. Co-culture of bacterial and fungal isolates were explored for production with the optimization of SSF parameters. Optimum $\mathrm{pH}$ and temperature for the enzyme production were observed to be 5.5 and $30^{\circ} \mathrm{C}$ respectively. At optimal growth conditions, the maximum tannase and gallic acid production observed was $39.24 \mathrm{U} / \mathrm{g}$ and $0.409 \mathrm{mg} / \mathrm{ml}$, respectively with $0.75 \% \mathrm{w} / \mathrm{v}$ tannic acid supplementation. Tannase was partially purified by ammonium sulfate precipitation method and acetone precipitation method. In ammonium sulfate precipitation method 7.48 fold and yield of $26.76 \%$ was observed. In case of acetone precipitation method to 3.13 fold and yield of $84.58 \%$ was observed. Scanning electron microscopy and Energy Dispersive X-ray Spectrometry of the best tannase producing combination revealed the presence of gallic acid crystals, spores of the fungal isolate. Morphological change in substrate indicated the growth of organism, efficient utilization of agro residue and production of gallic acid. The current research offers a agroindustrial waste as a good alternatives to synthetic tannic acid for production of tannase and gallic acid with high yield. (C) 2016 iGlobal Research and Publishing Foundation. All rights reserved.
\end{abstract}

Conference Proceedings: International Conference on Advances in Plant and Microbial Biotechnology (PMB2017); JIIT, Noida: February 02-04, 2017

Indo Global Journal of Pharmaceutical Sciences( ISSN 22491023 ; CODEN- IGJPAI; NLM ID: 101610675) indexed and abstracted in EMBASE(Elsevier), SCIRUS(Elsevier),CABI, CAB Abstracts, Chemical Abstract Services(CAS), American Chemical Society(ACS), Index Copernicus, EBSCO, DOAJ, Google Scholar and many more. For further details, visit http://iglobaljournal.com 